\title{
Qualidade microbiológica da água do Lago Igapó de Londrina - PR e caracterização genotípica de fatores de virulência associados a Escherichia coli enteropatogênica (EPEC) e E. coli produtora de toxina Shiga (STEC)
}

\section{Microbiological water quality of Igapó Lake Londrina - PR and genotypic characterization of virulence factors associated with enteropathogenic Escherichia coli (EPEC) and Shiga toxin-producing E. coli (STEC)}

\author{
Paulo Alfonso Schuroff'; Nicole Ribeiro de Lima²; Tatiane das Neves Burgos ${ }^{3}$; \\ Angélica Marim Lopes ${ }^{4}$; Jacinta Sanchez Pelayo5.
}

\begin{abstract}
Resumo
Esse trabalho teve como objetivo a detecção e quantificação de coliformes totais e Escherichia coli, no Lago Igapó, com a finalidade de avaliar a qualidade destas águas como próprias ou impróprias para recreação, além da caracterização genotípica de fatores de virulência associados a EPEC e STEC pela técnica da PCR. A área de estudo foi o Lago Igapó I, II, III e IV. As coletas foram realizadas mensalmente entre março de 2011 a fevereiro de 2012. A técnica utilizada para detecção e quantificação de Coliformes Totais e $E$. coli foi a do substrato cromogênico Colilert. Na PCR os genes eae e $b f p$ foram pesquisados para caracterizar o patotipo de EPEC típica; stxl, stx2, eae e hlyA o de STEC e as que apresentaram somente o gene eae foram caracterizadas como EPEC atípica. De acordo com a Resolução CONAMA 357/2005, foi observado que para a recreação de contato primário, apenas o Lago Igapó III foi classificado impróprio, já para recreação de contato secundário, todos os lagos apresentaram-se próprios. Além disso, pode ser observada uma forte relação entre o índice pluviométrico e os índices de E. coli no Lago Igapó, na qual em meses mais secos a sua quantidade decresce drasticamente, enquanto que em meses chuvosos se observava uma relação contrária. Das 97 cepas de E. coli isoladas, duas apresentaram o gene eae (EPEC atípica). Nenhum isolado apresentou os genes stxl, stx2, bfp e hlyA. Desse modo, esperamos conscientizar a população e os órgãos públicos da importância do monitoramento microbiológico das águas recreacionais para prevenção de surtos de infecções de veiculação hídrica.
\end{abstract}

Palavras-chave: Lago Igapó. Águas recreacionais. E. coli. Fatores de virulência.

\begin{abstract}
This work aimed at the detection and quantification of total coliforms and Escherichia coli in Igapó Lake, in order to evaluate the quality of these waters as proper or unfit for recreation, in addition to the genotypic characterization of virulence factors associated with EPEC and STEC by PCR. The study area was the Igapó Lake I, II, III and IV. Samples were collected monthly from March 2011 to February 2012. The technique used for the detection and quantification of Total Coliforms and $E$. coli was the Colilert chromogenic substrate. In the technique of PCR, the eae and $b f p$ genes were tested to characterize the

\footnotetext{
${ }^{1}$ Mestrando do Programa de Pós-Graduação em Microbiologia da Universidade Estadual de Londrina-UEL. E-mail:pauloalfonso@ hotmail.com

${ }^{2}$ Mestranda do Programa de Pós-Graduação em Microbiologia da Universidade Estadual de Londrina-UEL.E-mail: nicoleriblima@ hotmail.com.

3 Doutoranda do Programa de Pós-Graduação em Microbiologia da Universidade Estadual de Londrina - UEL. E-mail: tatianeburgos@hotmail.com

${ }^{4}$ Mestranda do Programa de Pós-Graduação em Microbiologia da Universidade Estadual de Londrina-UEL. E-mail: angelopes_8@, hotmail.com

${ }^{5}$ Doutora em Ciências Biológicas (Microbiologia) pela Universidade de São Paulo, Brasil. Professora Associado do Departamento de Microbiologia, Laboratório de Bacteriologia da Universidade Estadual de Londrina. E-mail: jspelayo@gmail.com
} 
typical EPEC pathotype; stxl, stx2, eae and hlyA the STEC pathotype and the samples that presented only the eae gene were characterized as atypical EPEC. According to CONAMA Resolution 357/2005, it has been observed that only Igapó Lake III was rated inappropriate for primary contact recreation, while for secondary contact recreation, all lakes were considered appropriate. Moreover, a strong relationship between rainfall and $E$. coli indices in Igapó Lake can be observed, which in dry months the quantity drastically decreases, while in rainy months the opposite relationship was observed. Of the 97 strains of $E$. coli isolated, two had the eae gene (atypical EPEC). None of the isolates contained genes stxl, $s t x 2, b f p$ and $h l y A$. Thus, we hope to educate the population and public agencies of the importance of microbiological monitoring of recreational waters to prevent outbreaks of waterborne infections.

Palavras-chave: Igapó Lake. Recreational waters. E. coli. Virulence factors.

\section{Introdução}

O suprimento de água doce de boa qualidade é essencial para o desenvolvimento econômico, a manutenção da diversidade e para a continuidade dos ciclos de vida no planeta (REBOUÇAS, 2002).

A crescente expansão demográfica e industrial observada nas últimas décadas trouxe como consequência o comprometimento das águas dos rios, lagos e reservatórios, sendo estes afetados por diversos poluentes. Desse modo, a água pode trazer riscos à saúde em face de sua má qualidade, servindo de veículo para vários agentes biológicos e químicos (CETESB, 2010). Os principais agentes biológicos encontrados nas águas contaminadas são as bactérias patogênicas, como Salmonella, Shigella e Vibrio; os vírus, destacando-se os da poliomielite e hepatite A; e os protozoários, como Giardia e Cryptosporidium (TOZE, 1999).

A detecção especifica e direta destes microrganismos patogênicos na água é extremamente difícil e economicamente inviável. Assim, se utilizam outros microrganismos como os indicadores para avaliar o nível de contaminação fecal (VON SPERLING, 2005). Dentre eles temos as bactérias denominadas "coliformes", as quais pertencem à família Enterobacteriaceae, sendo a Escherichia coli o principal indicador de contaminação fecal recente, por se tratar de uma bactéria termotolerante e de origem exclusivamente fecal (WILKINSON et al., 1995).
Em alguns casos, a bactéria $E$. coli pode estar associada à infecção intestinal, tanto em crianças como em adultos, sendo conhecidas como E. coli diarreiogênicas. Dois patotipos, $E$. coli enteropatogênica (EPEC) típica e atípica e E. coli produtora de toxina Shiga (STEC), são considerados importantes agentes causais de diarreia, principalmente nos países em desenvolvimento (KAPER; NATARO; MOBLEY, 2004). A infecção por STEC pode causar casos esporádicos de diarreia, colite hemorrágica e Síndrome Hemolítica Urêmica (SHU), constituindo-se em um dos principais causadores de insuficiência renal, na forma aguda ou crônica (LEOTTA et al., 2005).

De acordo com a finalidade para qual a água vai ser utilizada, a mesma requer características microbiológicas qualitativas e quantitativas diferentes (BRANDÃO, 2005). Nos ambientes aquáticos destinados à recreação (como lagos, cachoeiras, balneários e piscinas) estas exigências seguem as normas estabelecidas pela Resolução CONAMA N ${ }^{\circ}$ 357/2005 (BRASIL, 2005).

Essa resolução no seu artigo $2^{\circ}$, parágrafos I, II e III, de acordo com a concentração de sais, classifica as águas do território brasileiro em águas doces, salobras e salinas. A classificação das águas doces, salobras e salinas do território Nacional é feita considerando a qualidade requerida para os seus usos preponderantes. As águas doces, objeto deste estudo, apresentam cinco classes de classificação: Especial, Classe I, Classe II, Classe III e Classe IV, que estão demonstradas na tabela 1. 
Tabela 1 - Classes de águas doces.

\begin{tabular}{|c|c|}
\hline Classe & Águas que podem ser destinadas \\
\hline Especial & $\begin{array}{l}\text { - Ao abastecimento para consumo humano, com desinfecção; } \\
\text { - À preservação do equilíbrio natural das comunidades aquáticas; } \\
\text { - À preservação dos ambientes aquáticos em unidades de conservação integral. }\end{array}$ \\
\hline Classe 1 & $\begin{array}{l}\text { - Ao abastecimento para consumo humano, após tratamento simplificado; } \\
\text { - À proteção das comunidades aquáticas; } \\
\text { - À recreação de contato primário, tais como natação, esqui aquático e mergulho, } \\
\text { conforme Resolução CONAMA } 274 \text { de } 2000 \text {; } \\
\text { - À irrigação de hortaliças que são consumidas cruas e de frutas que se desenvolvem } \\
\text { rentes ao solo e que sejam ingeridas cruas sem remoção de película; } \\
\text { - À proteção das comunidades aquáticas em terras indígenas. }\end{array}$ \\
\hline Classe 2 & $\begin{array}{l}\text { - Ao abastecimento para consumo humano, após tratamento convencional; } \\
\text { - À proteção das comunidades aquáticas; } \\
\text { - À recreação de contato primário, tais como natação, esqui aquático e mergulho, } \\
\text { conforme Resolução CONAMA } 274 \text { de } 2000 \text {; } \\
\text { - À irrigação de hortaliças, plantas frutíferas e de parques, jardins, campos de esporte e } \\
\text { lazer, com os quais o público possa vir a ter contato direto; } \\
\text { - À aqüicultura e à atividade de pesca. }\end{array}$ \\
\hline Classe 3 & $\begin{array}{l}\text { - Ao abastecimento para consumo humano, após tratamento convencional ou avançado; } \\
\text { - À irrigação de culturas arbóreas, cerealíferas e forrageiras; } \\
\text { - À pesca amadora; } \\
\text { - À recreação de contato secundário; } \\
\text { - À dessedentação de animais. }\end{array}$ \\
\hline Classe 4 & $\begin{array}{l}\text { - À navegação; } \\
\text { - À harmonia paisagística. }\end{array}$ \\
\hline
\end{tabular}

Fonte: Brasil (2005).

A atividade recreacional pode ser dividida em recreação de contato primário (atividades de contato direto e prolongado com a água, como natação) e de contato secundário (atividades em que o contato com a água é esporádico ou acidental e a possibilidade de ingerir água é pequena, como a navegação e pesca). As águas destinadas à prática de atividades recreacionais de contato primário são classificadas como classe 1 ou 2, enquanto que as atividades recreacionais de contato secundário são classificadas como classe 3 . Para as classes 1 e 2, no que se refere a coliformes termotolerantes e/ou $E$. coli, a Resolução 357/2005 (BRASIL, 2005) remete à Resolução CONAMA 274/2000 (BRASIL, 2001), que define que as águas destinadas à balneabilidade terão sua condição avaliada nas categorias própria e imprópria.

Assim, o objetivo principal deste estudo foi verificar as condições sanitárias das águas utilizadas para fins recreacionais no Lago Igapó em Londrina (PR), a partir da pesquisa do microrganismo indicador de contaminação fecal $E$. coli e caracterização genotípica de fatores de virulência associados a EPEC e STEC.

\section{Material e Métodos}

\section{Área de estudo}

O Lago Igapó, objeto desta pesquisa, se localiza na microbacia do Ribeirão Cambé, na cidade de Londrina, norte do estado do Paraná, Brasil, e devido à sua fragmentação por ruas e avenidas, é dividido no Lago Igapó I, II, III e IV. Foram monitorados quatro pontos de amostragem um em cada subdivisão do Lago Igapó, a escolha destes pontos foi feita com base nos locais com maior contingente de pessoas. 
Figura 1 - (a) Identificação da região de análise. (b) Pontos de coleta de amostras no Lago Igapó.

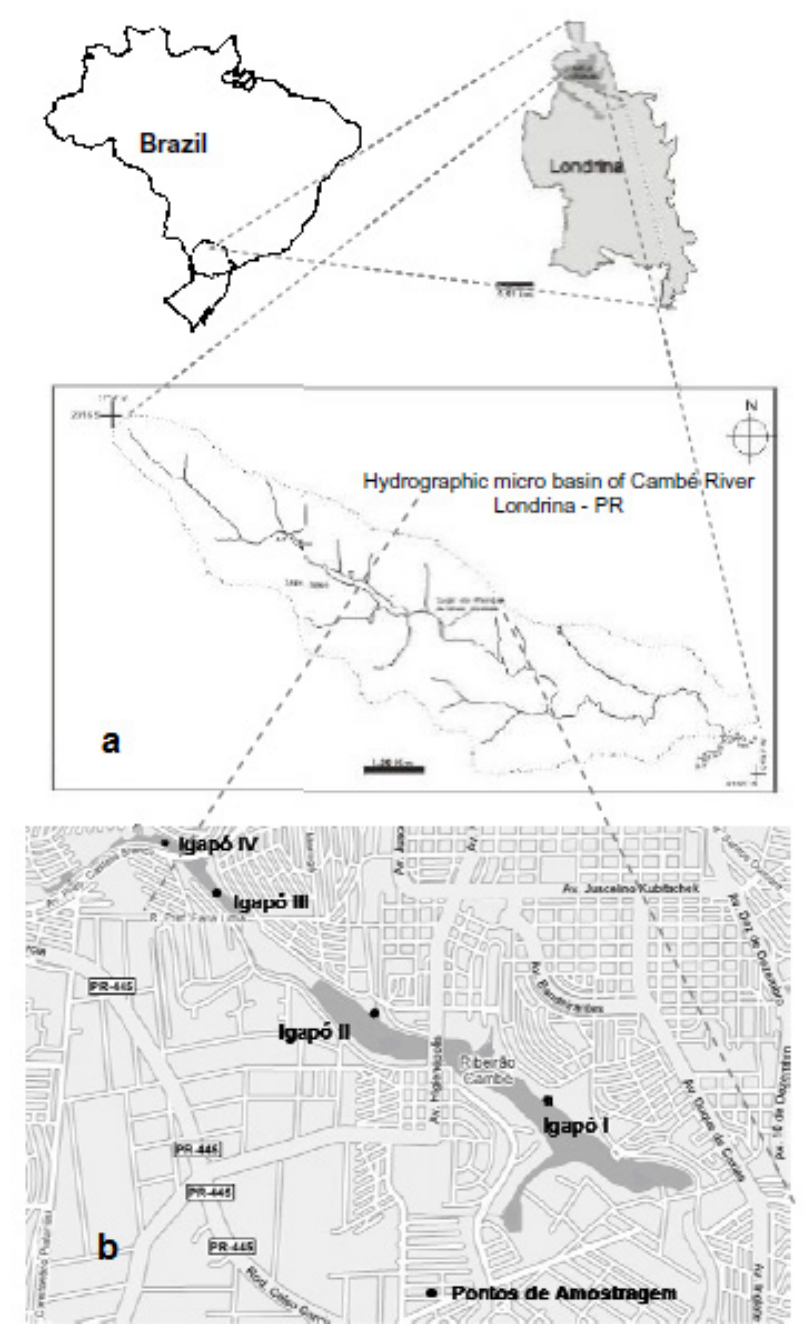

Fonte: Melquíades et al. (2008).

\section{Amostragem}

As coletas foram feitas mensalmente entre março de 2011 a fevereiro de 2012. As amostras de água foram coletadas próximas à margem do lago (profundidade aproximada de $70 \mathrm{~cm}$ ) em frascos de vidro estéreis, de $500 \mathrm{~mL}$, transportadas em caixas de isopor resfriadas até o Laboratório de Bacteriologia (Departamento de Microbiologia, $\mathrm{CCB}, \mathrm{UEL} /$ Londrina), mantidas a $4^{\circ} \mathrm{C}$ e analisadas em no máximo até 6 horas.
Pesquisa de coliformes totais e Escherichia coli

A técnica utilizada para detecção e quantificação de coliformes totais e E. coli foi a do substrato cromogênico Colilert (SOVEREIGN - USA), aprovado peloStandardMethods for the Examination of Water and Wastewater (AMERICAN PUBLIC ASSOCIATION, 2004).

O Colilert utiliza tecnologia de substrato definido (ONPG e MUG) para detecção de coliformes totais e E. coli. Os coliformes totais utilizam a enzima $\beta$-galactosidase para metabolizar o substrato o-nitrofenil- $\beta$-D-galactopiranosídeo (ONPG) adquirindo coloração amarela. E. coli utiliza a enzima $\beta$-glucuronidase para metabolizar o substrato 4-metil-umbeliferil- $\beta$-D-glucoronídeo (MUG), apresentando uma coloração fluorescente. Os resultados quantitativos foram expressos em Número Mais Provável (NMP)/100 mL e os microrganismos foram pesquisados nas amostras de água pura e diluída 1:10 em água estéril.

As amostras que apresentaram fluorescência foram semeadas em ágar MacConkey e incubadas a $37^{\circ} \mathrm{C}$ por 24 horas. Após este período, colônias com características presuntivas de $E$. coli foram submetidas à identificação bioquímica utilizando os meios EPM (TOLEDO; FONTES; TRABULSI, 1982a), MILi (TOLEDO; FONTES; TRABULSI, 1982b) e Citrato de Simmons. Os isolados bioquimicamente identificados como $E$. coli foram armazenados em ágar nutriente.

Pesquisa de genes de fatores de virulência através da PCR

Os genes eae e $b f p$ foram pesquisados para caracterizar o patotipo de EPEC típica; os genes stx1, stx2, eae e hlyA caracterizam o patotipo de STEC e as que só apresentaram o gene eae foram caracterizadas como EPEC atípica. As reações de amplificação foram realizadas da seguinte maneira: 
culturas em ágar Luria-Bertani foram suspendidas em $300 \mu \mathrm{L}$ de água deionizada e fervidas por 10 minutos para liberação e desnaturação do DNA bacteriano (ALBRIGHT; HUALA; AUSUBEL, 1989). A amplificação do DNA bacteriano foi realizada em volumes de $25 \mu \mathrm{L}$, contendo $2 \mu \mathrm{L}$ do lisado bacteriano (concentração de $40 \mathrm{ng} / \mathrm{mL}$ ), 200 $\mu \mathrm{M}$ de dNTPs (InvitrogenTM), 1,5 mM de $\mathrm{MgCl} 2$ (InvitrogenTM), 20 pmol de cada iniciador e 1,5
U Taq DNA polimerase (InvitrogenTM). Depois de amplificado, o produto de amplificação foi submetido à eletroforese em gel de agarose $1 \%$ a $2 \%$, dependendo do tamanho do fragmento amplificado, corado com o SYBR Safe (InvitrogenTM) e visualizado através de luz UV. A cepa EDL 933 ( $E$. coli $\mathrm{O} 157: \mathrm{H} 7)$ foi utilizada como controle positivo e a cepa HB 101 (E. coli K-12) como controle negativo.

Tabela 2- Sequência dos oligonucleotídeos pesquisados, tamanho dos fragmentos de DNA amplificados e temperatura de anelamento.

\begin{tabular}{clccc}
\hline Gene & Sequência do oligonucleotídeo $\left(\mathbf{5}^{\prime} \rightarrow 3^{\prime}\right)$ & $\begin{array}{c}\text { Fragmento } \\
\text { (pb) }\end{array}$ & Anelamento & Referência \\
\hline$b f p A$ & $\begin{array}{l}\text { (F) CAATGGTGCTTGCGCTTGGT } \\
\text { (R) GCCGCTTTATCCAACCTGGT }\end{array}$ & 326 & $60^{\circ} \mathrm{C}$ & $\begin{array}{c}\text { GUNZBURG; } \\
\text { TORNIEPORTH; } \\
\text { RILEY, 1995 }\end{array}$ \\
\hline eae & $\begin{array}{l}\text { (F) GACCCGGCACAAGCATAAGC } \\
\text { (R) CCACCTGCAGCAACAAGAGG }\end{array}$ & 384 & $60^{\circ} \mathrm{C}$ & PATON; PATON, \\
\hline$s t x l$ & $\begin{array}{l}\text { (F) ATAAATCGCCATTCGTTGACTAC } \\
\text { (R) AGAACGCCCACTGAGATCATC }\end{array}$ & 180 & $60^{\circ} \mathrm{C}$ & PATON; PATON, \\
\hline stxz & $\begin{array}{l}\text { (F) GGCACTGTCTGAAACTGCTCC } \\
\text { (R) TCGCCAGTTATCTGACATTCTG }\end{array}$ & 255 & $60^{\circ} \mathrm{C}$ & PATON; PATON, \\
\hline$h l y A$ & $\begin{array}{l}\text { (F) GCATCATCAAGCGTACGTTCC } \\
\text { (R) AATGAGCCAAGCTGGTTAAGCT }\end{array}$ & 534 & $60^{\circ} \mathrm{C}$ & PATON; PATON, \\
\hline
\end{tabular}

Fonte: Autores.

\section{Resultados e Discussão}

A quantificação de coliformes totais obtida em todas as amostras foi $>2419,6 \mathrm{NMP} / 100 \mathrm{~mL}$. A quantidade elevada destes microrganismos em todas as amostras indica a contaminação dos lagos por matéria orgânica, o que e natural em áreas verdes.

Na figura 2 estão distribuídos os resultados das 12 análises realizadas ao longo de 12 meses no Lago Igapó I, II, III e IV, relativos à determinação do NMP/100 mL da bactéria $E$. coli, onde podemos observar que os valores variaram muito. Nas amostras do Lago Igapó I variaram entre 0 e 410,6 NMP/100 $\mathrm{mL}$; do Lago II entre 8,6 e 1553,1 NMP/100 mL; do Lago III entre 31,0 e 5200,0 NMP/100 mL; e do Lago IV entre 52,0 e 4611,0 NMP/100 mL. De um modo geral, todos os lagos (com exceção do Igapó I entre abril a junho) apresentaram contaminação por E. coli, com destaque para o Lago Igapó III, que apresentou o maior índice, seguidos pelo Lago IV e II, sendo o Igapó I o lago com o menor nível de contaminação fecal (Figura 2).

Figura 2 - Variação das concentrações de E. coli nas águas do Lago Igapó I, II, III e IV.

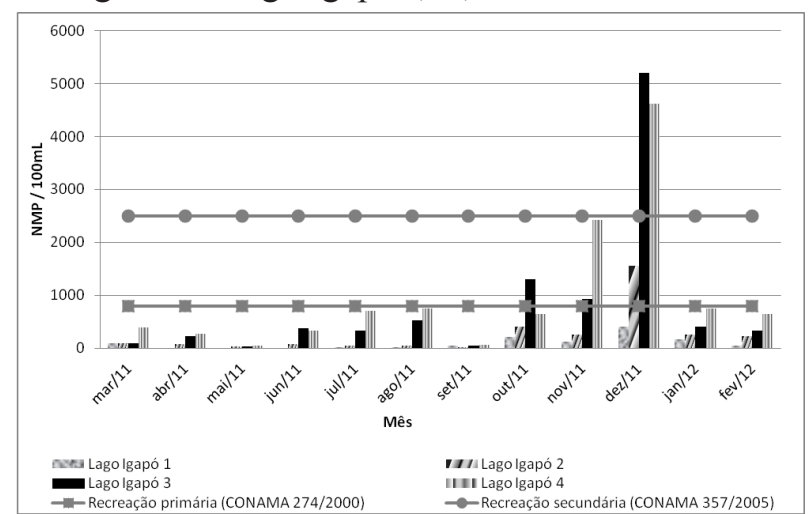

Fonte: Autores.

Relacionando os resultados com os critérios de avaliação da Resolução CONAMA n n 274/2000 (BRASIL, 2001), as águas analisadas dos quatro 
lagos só podem ser consideradas próprias para recreação de contato primário quando em $80 \%$ ou mais de um conjunto de amostras colhidas no mesmo local houver no máximo 800 E. coli/100 mL.

Segundo os resultados obtidos na análise dos quatro lagos, observamos que no Lago Igapó I todas as amostras coletadas apresentaram a quantidade de E. coli inferior a $800 \mathrm{NMP} / 100 \mathrm{~mL}$, considerando o lago, de acordo com a Resolução próprio para recreação de contato primário, sendo suas águas subdividida na categoria excelente (NMP de E. coli inferior a 200 em pelo menos $80 \%$ das amostras coletadas).

No Lago Igapó II apenas uma amostra ultrapassou o limite de $800 \mathrm{E}$. coli, enquanto as outras onze amostras $(91,7 \%)$ se enquadraram nos padrões estabelecidos pela CONAMA 274/2000 (BRASIL, 2001), logo o Lago II é considerado próprio para a recreação de contato primário, sendo suas águas subdividas na categoria muito boa (NMP de E. coli inferior a 400 em pelo menos $80 \%$ das amostras coletadas).

No Lago III encontramos uma situação inversa, pois este apresentou três mostras $(25 \%)$ com índices de contaminação superior a $800 \mathrm{NMP} / 100 \mathrm{~mL}$ e apenas nove amostras (75\%) com quantidade de $E$. coli inferior a $800 \mathrm{NMP} / 100 \mathrm{~mL}$. Portanto, o Lago Igapó III apresenta suas águas impróprias para recreação de contato primário de acordo com o estabelecido pela Resolução CONAMA 274/2000 (BRASIL, 2001).

NoLago IV cercade $80 \%$ de suas amostras possuem um número de $E$. coli inferior a $800 \mathrm{NMP} / 100 \mathrm{~mL}$, classificando-o como próprio a recreação de contato primário, com suas águas subdivididas na categoria satisfatória (NMP de E. coli inferior a 800 NMP/100 $\mathrm{mL}$ em pelo menos $80 \%$ das amostras coletadas).

Com relação à recreação de contato secundário, a resolução CONAMA 357/2005 (BRASIL, 2005) estabelece que a balneabilidade só pode ser considerada própria nas águas que apresentarem em $80 \%$ ou mais de um conjunto de amostras colhidas no mesmo local, o máximo de 2500 E. coli/100 mL. Analisando os quatro lagos chegamos a conclusão de que todos eles apresentam-se como próprios para este tipo de recreação, já que em apenas duas amostras (Lago III e IV em dez 2011) o limite de $2500 \mathrm{NMP} / 100 \mathrm{~mL}$ foi ultrapassado.

Lagos próprios e impróprios para recreação de contato primário também são apresentados na literatura. Amarante et al. (2007), na análise da Lagoa do Mondubim em Fortaleza - Ceará obtiveram que $80 \%$ das amostras possuíam no máximo 800 NMP/100 mL de E. coli, considerando a lagoa, de acordo com a Resolução 274/2000 (BRASIL, 2001), própria e satisfatória para recreação de contato primário. Em oposição a estes dados, Costa et al. (2012) ao pesquisarem a Lagoa do Catão também localizada em Fortaleza, obtiveram como resultado a classificação desta como imprópria para tal tipo de recreação.

Rego, Barros e Santos (2010) afirmam que a presença elevada de coliformes termotolerantes e E. coli em lagos e lagoas degradados indicam um risco potencial para a contaminação da população por doenças causadas por organismos patogênicos; já que a $E$. coli é um microrganismo indicador presente em altas quantidades nas fezes de humanos e outros animais de sangue quente.

Provavelmente no Lago Igapó III e IV a falta de infra-estrutura, como drenagem urbana e lixeiras, possam ser os principais agentes responsáveis pela sua degradação. Estes lagos enfrentam ainda grandes problemas de erosão e assoreamento. Enquanto isso, no Lago Igapó I e II, a presença de terrenos mais abertos e maior quantidade de mata ciliar, bem como um fraco assoreamento e maior infra-estrutura da região podem ter contribuído para os baixos índices de contaminação fecal.

Um segundo quesito avaliado neste trabalho foi a influência das chuvas sobre os níveis de contaminação nos quatro lagos. A precipitação mensal da cidade de Londrina - PR, nos períodos de março de 2011 a fevereiro de 2012, encontram-se no gráfico abaixo. 
Figura 3 - Precipitação mensal na cidade de Londrina - PR; no período de março de 2011 a fevereiro de 2012.

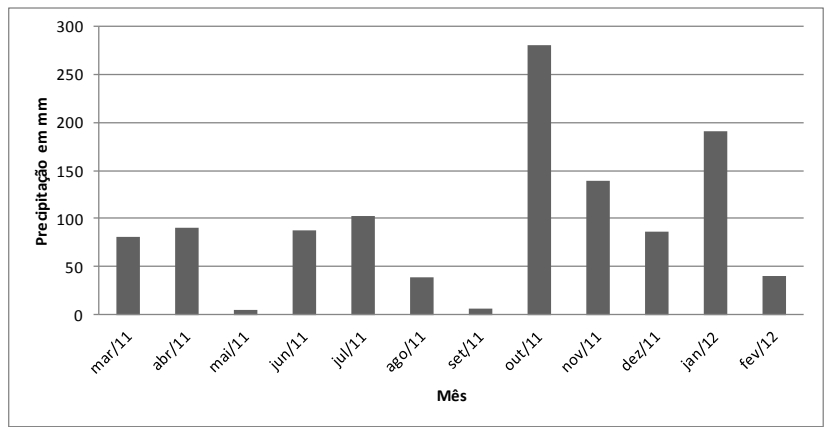

Fonte: Autores.

Podemos observar que nos meses de maio e setembro onde a precipitação foi de 5,2 e 6,2 mm respectivamente, o nível de contaminação fecal em todos os lagos foi extremamente baixo como pode ser observado na Figura 2. Já nos meses de outubro a dezembro onde o acumulado foi de 505,9 mm os índices de contaminação apresentaram-se bastante elevados.

Portanto, o parâmetro microbiológico $E$. coli foi altamente influenciado pela sazonalidade, na qual o escoamento superficial das chuvas aumentou consideravelmente os níveis de contaminação, principalmente nos lagos mais degradados (Igapó III e IV).

Segundo Emiliani e Gonzalez (1998), o número de coliformes fecais está diretamente relacionado com os níveis de chuva local. O aumento dos coliformes associado ao aumento do nível hidrométrico indica a presença de contaminadores de origem difusa.

Outros autores em pesquisas com água em ambientes urbanos também encontraram situações parecidas com a descrita neste trabalho. Lemos, Ferreira Neto e Dias (2010) encontraram variação na qualidade bacteriológica da água comprometendo a Lagoa do Apodi, no Rio Grande do Norte, principalmente após o período das chuvas.
Amarante et al. (2007) verificaram que na Lagoa do Mondubim em Fortaleza - Ceará, os maiores valores de coliformes termotolerantes e E. coli, ocorreram no período chuvoso (março e abril). Já Ribeiro et al. (2010), mostraram que três parques do Distrito Federal (Parques Águas Claras, Parque Asa Sul e Parque Olhos D’água) apresentaram coliformes termotolerantes em concentrações crescentes nos meses de outubro a dezembro (período de chuvas) e valores decrescentes de março a maio (período da seca).

Por fim, na pesquisa de genes de fatores de virulência, das 97 cepas de $E$. coli isoladas, apenas duas $(2 \%)$ apresentaram somente o gene eae (EPEC atípica), sendo a primeira isolada do Lago Igapó I e a segunda do Lago Igapó IV. Nenhum isolado apresentou os genes stx $1, s t x 2, b f p$ e $h l y A$. As outras 95 cepas não se enquadraram em nenhum dos dois patotipos pesquisados (EPEC típica e STEC). A associação dos fatores de virulência nas amostras de E. coli dos diferentes lagos é apresentado na Tabela 3.

Tabela 3 - Associação dos fatores de virulência com as amostras de $E$. coli isoladas.

\begin{tabular}{|c|c|c|c|c|c|c|c|c|}
\hline \multirow[b]{2}{*}{ Isolado } & \multicolumn{5}{|c|}{ PCR } & \multirow[b]{2}{*}{ Patotipo } & \multirow[b]{2}{*}{ Lago } & \multirow[b]{2}{*}{ Mês da coleta } \\
\hline & eae & bfpA & stat 1 & $s t x 2$ & hlyA & & & \\
\hline 11 & $\mathrm{x}$ & & & & & EPEC atípica & Igapó I & Nov/2011 \\
\hline 63 & $\mathrm{x}$ & & & & & EPEC atipica & Igapó $\mathrm{TV}$ & $\operatorname{Jun} / 2011$ \\
\hline
\end{tabular}

Fonte: Autores.

E. coli que possuem o perfil eae+/ bfp-/ stx- têm sido correlacionadas com diarreia. Além disso, as cepas de EPEC atípica possuem um perfil genômico característico que possibilita a aquisição de fatores de virulência típicos de outros patotipos de $E$. coli patogênicas (KAPER; NATARO; MOBLEY, 2004).

Outros estudos também relatam a prevalência do gene eae em linhagens de EPEC isoladas de águas contaminadas. Melo (2006) ao determinar a ocorrência de fatores de virulência em amostras de E. coli isoladas de lagoas frequentadas por banhistas no Parque Estadual do Rio Doce - MG, 
obteve em 80 isoladas a presença de dois $(2,5 \%)$ com gene eae. Sidhu et al. (2013), ao analisarem 300 cepas de $E$. coli isoladas de água superficial na Austrália, constataram uma prevalência de $11 \%$ de EPEC em seus isolados, mostrando assim os riscos destas águas à saúde, utilizadas principalmente para fins recreacionais.

O monitoramento de genes de virulência em linhagens de E. coli ambientais é uma tarefa indispensável para o controle de $E$. coli patogênica no ambiente e em suprimentos de água e alimento. Os dados obtidos neste trabalho contribuem para ampliar o estudo desta espécie em fontes ambientais, já que nestas fontes seu estudo é ainda bastante escasso.

\section{Conclusão}

A partir dos resultados obtidos, podemos concluir que as águas do Lago Igapó I, II, III e IV; apresentaram-se contaminadas pela bactéria E. coli, além da presença de $E$. coli diarreiogênica, sendo encontrado neste estudo duas cepas de EPEC atípica. Dos lagos estudados, apenas um (Igapó III), apresentou-se impróprio para recreação de contato primário. Já para recreação de contato secundário, todos os lagos foram classificados como próprios. Outro ponto observado foi o fato da qualidade da água ser mais comprometida nos períodos de chuva, mostrando assim a influencia da sazonalidade sobre a quantidade da bactéria $E$. coli.

Portanto, para se garantir uma maior qualidade destes lagos tanto para atividades recreacionais da população de Londrina quanto para a preservação da comunidade aquática que ali vivem, fazemse necessárias medidas como o monitoramento microbiológico, investimentos em infra-estrutura, além da conscientização da população sobre a importância de se preservar este patrimônio natural da cidade de Londrina, tudo isso a fim de impedir danos ao sistema aquático e à saúde humana.

\section{Agradecimentos}

Os autores agradecem à Universidade Estadual de Londrina e a Fundação Araucária pelo auxílio da bolsa de estudo.

\section{Referências}

ALBRIGHT, L. M.; HUALA, E.; AUSUBEL, F. M. Prokaryotic signal transduction mediated by sensor and regulator protein pairs. Annual Review of Genetics, Palo alto, v. 23, p. 311-336, 1989.

AMARANTE, A.; PACHECO, C.; LIMA, I.; GOMES, B. Avaliação da qualidade da água de um ecossistema lacustre urbano da bacia do rio Maranguapinho - Fortaleza-CE: Lagoa do Mondubim. In: CONGRESSO DE PESQUISA E INOVAÇÃO DA REDE NORTE E NORDESTE DE EDUCAÇÃO TECNOLÓGICA, 2., 2007, João Pessoa. Anais... João Pessoa: CONNEPI, 2007. Disponível em: <http://www.redenet.edu. br/publicacoes/arquivos/20080212_093547 MEIO-036.pdf $>$. Acesso em: 26 maio 2012.

AMERICAN PUBLIC HEALTHASSOCIATION. Standard methods for the examination of water and wastewater. 21. ed. Washington, 2004.

BRANDÃO, L. A. M. P. Melhoria da qualidade da água em bacia de decantação de uma mina de ferro - S. A. Mineração da Trindade. Samitri. 2005. Dissertação (Mestrado em Recursos Hídricos) - Universidade Federal de Ouro Preto, Ouro Preto, 2005.

COMPANHIA DE TECNOLOGIA E SANEAMENTO AMBIENTAL - CETESB. Água: relatório de qualidade das águas interiores do Estado de São Paulo - 2005. Disponível em: $<$ http://www.cetesb.sp.gov.br/Agua/relatorios/ rios/rel_aguas_int_2005/rel_aguas_int_2005. zip>. Acesso em: $2 \overline{7}$ abr. 2011.

BRASIL. Conselho Nacional do Meio Ambiente. Resolução $\mathrm{n}^{\circ}$ 274, de 29 de novembro de 2000. Dispõe sobre a qualidade das águas de balneabilidade e altera o disposto na resolução CONAMA n ${ }^{\circ} 20$, de 18 de julho de 1986. Diário Oficial da República Federativa do Brasil, Brasília, Seção 1, 2001. 
Resolução $\mathrm{n}^{\circ} 357$ de 17 de março de 2005. Dispõe sobre a classificação dos corpos de água e diretrizes ambientais para o seu enquadramento, bem como estabelece as condições e padrões de lançamento de efluentes, e dá outras providências. Diário Oficial da União, Brasília, Seção 1, 2005.

COSTA, P. A. C.; PACHECO, J. M. S.; ANDRADE, T. J. S.; NOGUEIRA, W. E. D.; CASTRO, J. I. A.; SILVA, D. M. Avaliação da qualidade microbiológica da água da Lagoa do Catão no Mondubim - Fortaleza - CE. In: CONGRESSO NORTE E NORDESTE DE PESQUISA E INOVAÇÃO, 2012, Palmas. Anais... Palmas: CONNEPI, 2012. Disponível em: $<$ http://propi.ifto.edu.br/ocs/index.php/connepi/vii/ paper/ viewFile/5088/2390>. Acesso em: 30 jul. 2012.

EMILIANI,F.; GONZÁLES, S.M.P. Bacteriological quality of Bendetti Lake (Santo Tome, Santa Fé Province, Argentina) and associated enviromental variables. Revista Argentina de Microbiologia, Buenos Aires, v. 30, p. 30-38, 1998.

GUNZBURG, S. T.; TORNIEPORTH, N. G.; RILEY, L. W. Identification of enteropathogenic Escherichia coli by PCR-based detection of the bundle-forming pilus gene. Journal of Clinical Microbiology, Washington, v. 33, p. 1375-1377, 1995.

KAPER, J. B.; NATARO, J. P.; MOBLEY, H. L. T. Pathogenic Escherichia coli. Nature Reviews Microbiology, London, v. 2, p. 123-138, 2004.

LEMOS, M.; FERRERIA NETO, M.; DIAS, N. S. Sazonalidade e variabilidade espacial da qualidade da agua na Lagoa do Apodi, RN. Revista Brasileira de Engenharia Agrícola e Ambiental, Campina Grande, v. 14, p. 155-164, 2010.

LEOTTA, G. A.; CHINEN, S.; EPSZTEYN, S.; MILIWEBSKY, E.; MELAMED, I. C.; MOTTER, M.; FERRER, M.; MAREY, E.; RIVAS, M. Validación de una Técnica de PCR múltiple para la detección de Escherichia coli productor de toxina Shiga. Revista Argentina de Microbiologia, Buenos Aires, v. 37, p. 1-10, 2005.

MELO, S. K. Caracterização de fatores de virulência em amostras de Escherichia coli isoladas de lagoas do Parque Estadual do Rio Doce, Minas Gerais. 2006. Dissertação (Mestrado em Engenharia Ambiental) - Universidade Federal de Ouro Preto, Ouro Preto, 2006.
MELQUÍADES, F. L.; GONÇALVES, G. W. P.; SILVA, W. D.; PARREIRA, P. S.; APPOLONI, C. R. Monitoramento de metais nos lagos igapó em Londrina, PR, usando a metodologia de EDXRF. Semina: Ciências Exatas e da Terra, Londrina, v. 29, n. 2, p. 129-138, 2008.

PARANÁ. Secretaria de Estado da Agricultura e do Abastecimento - SEAB. Precipitação pluviométrica regional. Disponível em: <http://www.agricultura. pr.gov.br/arquivos/File/deral/pluvio.xls $>$. Acesso em: 22 maio 2014.

PATON, A. W.; J. C. PATON. Detection and characterization of Shiga toxigenic Escherichia coli by using multiplex PCR assays for stx 1 , stx2, eaeA, enterohemorrhagic E. coli hlyA, rfbO111, and rfbO157. Journal of Clinical Microbiology, Washington, v. 36, p. 598-602, 1998.

REBOUÇAS, A. C. Água doce no mundo e no Brasil. In: REBOUÇAS, A. C.; BRAGA, B.; TUNDISI, J. G. Águas doces no Brasil: capital ecológico, uso e conservação. 2. ed. São Paulo: Escrituras, 2002.

REGO, N. A. C; BARROS, S. R; SANTOS, J. W. B. Avaliação espaço-temporal da concentração de coliformes termotolerantes na lagoa encantada, Ilhéus, BA. Revista Eletrônica do Prodema, Fortaleza, v. 4, p. 55-69, 2010.

RIBEIRO, M. R.; SOUSA, S. R.; MUNIZ, D. H. F.; SILVA, M. C.; OLIVEIRA-FILHO, E. C. Caracterização microbiológica e físico-química de águas superficiais em parques urbanos no Distrito Federal. Universitas: Ciências da Saúde, Brasília, v. 8, p. 15-34, 2010.

SIDHU, J. P.S.; AHMED, W.; HODGERS, L.; TOZE, S. Occurrence of virulence genes associated with diarrheagenic pathotypes in Escherichia coli isolates from surface water. Applied and Environmental Microbiology, Washington, v. 79, p. 328-335, 2013.

TOLEDO, M. R. F., FONTES, C. F., TRABULSI, L. R. EPM: modificação do meio de Rugai e Araújo para realização simultânea dos testes de produção de gás a partir da glicose, H2S, urease triptofanodesaminase. Revista Microbiologia, São Paulo, v. 13, p. 309-315, 1982a.

TOLEDO, M. R. F., FONTES, C. F., TRABULSI, L. R. MILi: um meio para realização dos testes de motilidade, indol e lisina-descarboxilase. Revista Microbiologia, São Paulo, v. 13, p. 230-235, 1982 b. 
TOZE, S. PCR and detection of microbial pathogens in water and wastewater. Water Research, New York, v. 33, p. 3545-3556, 1999.

VON SPERLING, M. Introdução à qualidade das águas e ao tratamento de esgotos: princípios do tratamento biológico de águas residuárias. Belo Horizonte: Ed. UFMG, 2005

WILKINSON, J.; JENKINS, A.; WYER, M.; KAY, D. Modelling faecal coliform dynamics in streams and rivers. Water Research, New York, v. 29, p. 847-855, 1995. 